\title{
Ependymal Cell
}

National Cancer Institute

\section{Source}

National Cancer Institute. Ependymal Cell. NCI Thesaurus. Code C13003.

A cell that lines cavities in the central nervous system. It is considered to be a type of glial cell. 